\title{
The Newt Smith Site (41HE78), Henderson County, Texas
}

Timothy K. Perttula

Heritage Research Center, Stephen F. Austin State University

Follow this and additional works at: https://scholarworks.sfasu.edu/ita

Part of the American Material Culture Commons, Archaeological Anthropology Commons, Environmental Studies Commons, Other American Studies Commons, Other Arts and Humanities Commons, Other History of Art, Architecture, and Archaeology Commons, and the United States History Commons

Tell us how this article helped you.

This Article is brought to you for free and open access by the Center for Regional Heritage Research at SFA ScholarWorks. It has been accepted for inclusion in Index of Texas Archaeology: Open Access Gray Literature from the Lone Star State by an authorized editor of SFA ScholarWorks. For more information, please contact cdsscholarworks@sfasu.edu. 


\section{The Newt Smith Site (41HE78), Henderson County, Texas \\ Creative Commons License \\ (c) $($ ) $(9)$}

This work is licensed under a Creative Commons Attribution-NonCommercial 4.0 International License 


\title{
The Newt Smith Site (41HE78), Henderson County, Texas
}

\author{
Timothy K. Perttula
}

\section{Introduction}

The Newt Smith site (41HE78) is probably an ancestral Caddo cemetery and habitation site in the Coon Creek valley of the Post Oak Savannah in the Trinity River basin in East Texas. In April 1931, a Mrs. A. G. Hughes of Poynor, Texas, donated a single Caddo vessel to The University of Texas. That vessel is in the collections of the Texas Archeological Research Laboratory at The University of Texas at Austin (TARL).

\section{The Caddo Ceramic Vessel from the Newt Smith Site}

SITE NAME OR SITE NUMBER: Newt Smith

VESSEL NO.: 1

VESSEL FORM: Bottle with a probable short (but broken) neck

NON-PLASTICS AND PASTE: grog

RIM AND LIP FORM: N/A

CORE COLOR: $\mathrm{G}$ (fired in a reducing environment and cooled in the open air)

INTERIOR SURFACE COLOR: very dark grayish-brown

EXTERIOR SURFACE COLOR: brown; fire clouds on the rim, body, and base

WALL THICKNESS (IN MM): neck, $6.5 \mathrm{~mm}$

INTERIOR SURFACE TREATMENT: none

EXTERIOR SURFACE TREATMENT: burnished

HEIGHT (IN CM): 19.7+

ORIFICE DIAMETER (IN CM): 5.1

DIAMETER AT BOTTOM OF RIM OR NECK (IN CM): 5.8; maximum body diameter is $14.0 \mathrm{~cm}$

BASE DIAMETER (IN CM) AND SHAPE OF BASE: 8.9; circular and concave

ESTIMATED VOLUME (IN LITERS): 0.7+ 


\section{DECORATION (INCLUDING MOTIF AND} ELEMENTS WHEN APPARENT): The vessel body has three horizontal engraved lines below the base of the neck and a single horizontal engraved line above the vessel base. The remainder of the body has three stacked sets of curvilinear, oval, triangular (with a nested oval), and circular engraved elements, and the uppermost elements have a small central engraved circle (Figure 1). The same uppermost elements are either in or attached to engraved zones with triangular hatched corners. The nested oval engraved element is seen in both Var. A and Var. $F$ of Poynor Engraved vessels in the upper Neches River basin (Perttula 2011:Figure 6-65).

PIGMENT USE AND LOCATION ON VESSEL: none

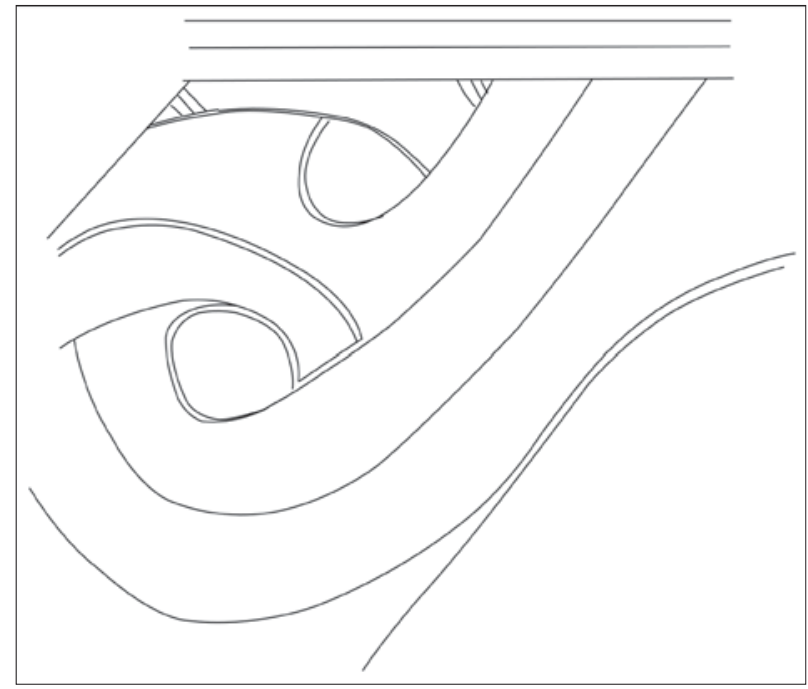

Figure 1. Decorative elements on a Poynor Engraved bottle from the Newt Smith site (41HE78).

TYPE AND VARIETY (IF KNOWN): Poynor Engraved

\section{Summary and Conclusions}

A single ancestral Caddo ceramic vessel from the Newt Smith site (41HE78) was donated to the University of Texas in 1931. The Newt Smith site is in the Coon Creek valley in the Trinity River basin in East Texas. The short-necked bottle from the site is a Poynor Engraved vessel, and nested oval elements on the bottle that resemble upper Neches River basin regional varieties Var. A and Var. F, suggest that the vessel came from a Caddo burial that likely dates from the early part of the Frankston phase, from ca. A.D. 1400-1480 (Perttula 2011:Table 6-37).

\section{Acknowledgements}

Thanks to Marybeth Tomka and Jonathan Jarvis for providing access to the Newt Smith site vessel in the TARL collections. Lance Trask prepared the figure in this article.

\section{References Cited}

Perttula, T. K.

2011 The Ceramic Artifacts from the Lang Pasture Site (41AN38) and the Place of the Site within an Upper Neches River Basin Caddo Ceramic Tradition. In Archeological Investigations at the Lang Pasture Site (41AN38) in the Upper Neches River Basin of East Texas, assembled and edited by T. K. Perttula, D. B. Kelley, and R. A. Ricklis, pp. 145-320. Archeological Studies Program Report No. 129, Texas Department of Transportation, Environmental Affairs Division, Austin. 